\title{
Efektivitas Kinerja Pegawai di Kantor Kelurahan Lanrisang Kecamatan Lanrisang Kabupaten Pinrang
}

\author{
Aris Baharuddin ${ }^{1}$, Asma $^{2} \&$ Risma Niswaty $^{3}$ \\ ${ }^{1}$ Politeknik Informatika Nasional (Polinas), Makassar \\ ${ }^{2}$ Pendidikan Administrasi Perkantoran FIS UNM
}

\begin{abstract}
ABSTRAK
Penelitian ini bertujuan untuk mengetahui efektivitas kinerja pegawai di kantor Kelurahan Lanrisang Kecamatan Lanrisang Kabupaten Pinrang. Penelitian ini merupakan penelitian deskriptif kuantitatif, populasi penelitian sebanyak delapan orang. Teknik pengumpulan data yang digunakan adalah observasi, angket, wawancara dan dokumentasi. Kemudian analisis data yang digunakan adalah analisis persentase. Hasil penelitian menunjukkan bahwa kinerja pegawai pada Kantor Kelurahan Lanrisang Kecamatan Lanrisang Kabupaten Pinrang berdasarkan indikator sasaran kerja pegawai (SKP) dengan sub indikator kuantitas, kualitas, waktu dan biaya sebesar 73,66 \% termasuk dalam kategori cukup efektif dan indikator perilaku kerja dengan sub indikator orientasi pelayanan, integritas, komitmen, disiplin, kerja sama dan kepemimpinan sebesar 86,30 \% termasuk dalam kataegori efektif. Dengan demikian efektivitas kinerja pegawai di Kantor Kelurahan Lanrisang Kecamatan Lanrisang Kabupaten Pinrang sebesar 81,88 $\%$ termasuk dalam kategori efektif.
\end{abstract}

Kata kunci: Efektivitas, Kinerja, Pegawai

\begin{abstract}
This study aims to determine the effectiveness of employee performance in the office Lanrisang Village District Lanrisang Pinrang District. This research is quantitative descriptive research, population of research as many as eight people. Data collection techniques used were observation, questionnaires, interviews and documentation. Then the data analysis used is percentage analysis. The result of the research shows that the performance of the employees at Lanrisang Village Office Lanrisang District Pinrang Regency based on the indicator of employee work target (SKP) with sub indicator quantity, quality, time and cost equal to 73,66\% included in category of effective and work behavior indicator with sub indicator of orientation Service, integrity, commitment, discipline, cooperation and leadership equal to $86.30 \%$ included in effective category. Thus the effectiveness of the performance of employees in the Village Office Lanrisang Lanrisang District Pinrang Regency of $81.88 \%$ included in the category effective.
\end{abstract}

Keywords: Effectiveness, Performance, Employee

\section{PENDAHULUAN}

Setiap organisasi tidak mungkin bisa sukses tanpa adanya Sumber Daya Manusia (SDM) di balik organisasi tersebut (Ambarwati, 2005; Halim \& Mas' ud, 2005; Hariandja, 2002; Nurillah \& Muid, 2014; RE, 2003; Ruky, 2002). Oleh karena itu, pentingnya SDM dalam suatu organisasi menuntut setiap organisasi mendapatkan pegawai yang berkualitas untuk 
menjalankan roda organisasi. Peningkatan kualitas sumber daya pegawai menjadi sangat urgen dan perlu dilakukan secara terencana, terarah dan berkesinambungan dalam rangka meningkatkan kemampuan dan profesionalisme. Sasaran dari pengembangan sumber daya pegawai adalah untuk meningkatkan kinerja operasional pegawai dalam melaksanakan tugastugas pemerintahan.

Pegawai merupakan aset utama organisasi yang harus dikelola dengan baik. Pengelolaan pegawai yang baik harus dimulai sejak perekrutan pegawai, penyeleksian, penempatan pegawai sesuai dengan kemampuannya sehingga pegawai dapat memiliki kinerja yang baik pula (Haryadi, 2009). Kedudukan dan peranannya yang penting menyebabkan pegawai senantiasa dituntut supaya memiliki kesetiaan dan kekuatan penuh dalam menjalankan tugas-tugasnya. Dalam hal ini pegawai harus bekerja seefektif dan seefisien mungkin agar tujuan organisasi atau instansi dapat tercapai. Tujuan organisasi dapat diraih semaksimal mungkin apabila didukung oleh efektivitas kinerja dari para pegawai.

Afrizal (2009) memberikan pendapatnya bahwa "Efektivitas merupakan suatu keadaan yang menunjukkan sejauh mana rencana dapat tercapai. Semakin banyak rencana yang dapat dicapai, semakin efektif pula kegiatan tersebut". Dengan demikian, perkembangan dan kemajuan di berbagai bidang selalu mengedepankan efektivitas kinerja para pegawai. Terciptanya efektivitas kinerja pegawai yang baik diharapkan mampu menjamin kelancaran pelayanan terhadap masyarakat secara baik dan tepat.

Kinerja merupakan hasil kerja secara kualitas dan kuantitas yang dapat dicapai oleh seorang pegawai dalam melaksanakan tugas sesuai dengan tanggung jawab yang diberikan kepadanya (Brahmasari \& Suprayetno, 2009; Siregar \& Saridewi, 2016). Dalam sebuah lembaga pemerintah, kinerja merupakan hal yang sangat penting guna mewujudkan tata kelola pemerintahan yang baik (good governance) dan pemerintahan yang bersih (clean governance), serta mendukung tugas-tugas pemerintah untuk memberikan pelayanan yang terbaik kepada masyarakat (Rahmanurrasjid, 2008). Dengan memiliki efektivitas kerja pegawai yang baik akan mampu menjamin tercapainya tujuan organisasi secara maksimal. Salah satu lembaga pemerintah yang memberikan pelayanan kepada masyarakat adalah Kelurahan. Kelurahan adalah daerah pemerintahan terendah langsung di bawah kecamatan dan dipimpin oleh seorang lurah (Wenda \& Akib, 2015).

Berdasarkan observasi awal yang dilakukan oleh peneliti pada tanggal 15 September 2016, fakta yang didapat yaitu kinerja pegawai dalam penyelenggaraan pemerintahan di Kantor Kelurahan Lanrisang Kecamatan Lanrisang Kabupaten Pinrang dinilai masih kurang efektif, hal ini ditunjukkan dengan adanya beberapa pegawai bekerja tidak sesuai dengan tugas pokok dan fungsinya serta tanggungjawabnya dalam menyelesaikan pekerjaan, sehingga pekerjaan yang dihasilkan belum maksimal dan berpengaruh pada kualitas dan kuantitas pekerjaan. Pegawai kurang teliti dalam bekerja seperti saat mengagendakan surat pindah domisili, karena kurang ketelitian sehingga salah penempatan dalam buku agenda. Selain itu, masih adanya pegawai yang belum sepenuhnya paham menggunakan komputer dengan baik, sehingga menghambat penyelesaian pekerjaan (Wawointana, Akib, Tahmir, \& Kerebungu, 2016).

Dengan demikian, setiap organisasi membutuhkan tenaga-tenaga yang mempunyai motivasi kerja yang tinggi, mau bekerja, dan penuh tanggung jawab (Tadampali, Hadi, \& Salam, 2016). Mereka memandang kerja bukan semata-mata sebagai sumber penghasilan, tetapi 
merupakan kesempatan untuk mengembangkan diri, mengembangkan sesuatu yang berarti bagi perusahaan. Tolok ukur peningkatan kualitas sumber daya manusia dalam organisasi adalah semangat berkinerja, yang mendorong individu berkarya melebihi kemampuan yang sebelumnya ditampakkan.

\section{METODE PENELITIAN}

Penelitian ini menggunakan jenis penelitian kuantitatif. Populasi dalam penelitian ini adalah seluruh Pegawai Kantor Kelurahan Lanrisang Kecamatan Lanrisang Kabupaten Pinrang yang berjumlah 8 orang. Mengingat jumlah pegawai di Kantor Kelurahan Lanrisang Kecamatan Lanrisang Kabupaten Pinrang tidak terlampau besar, maka peneliti mengadakan penelitian pada seluruh populasi. Teknik pengumpulan data yang digunakan adalah: 1) Observasi, 2) Angket, 3) Wawancara, 4) Dokumentasi. Sesuai dengan permasalahan dan tujuan penelitian yang diajukan, maka data yang berhasil dikumpulkan diolah dengan teknik pengolahan distribusi untuk kepentingan analisis persentase (\%) dengan menggunakan rumus sebagaimana yang dikemukakan oleh Anas (2014):

$$
\begin{aligned}
& \mathrm{P}=\frac{F}{N} \mathrm{X} 100 \% \\
& \mathrm{P}=\text { Angka persentase } \\
& F=\text { Frekuensi yang dicari persentasenya } \\
& N=\text { Jumlah frekuensi/banyak responden }
\end{aligned}
$$

Untuk analisis data digunakan rumus yang dikemukakan oleh Ali (2013), yaitu:

$$
\begin{aligned}
& \%=\frac{\mathrm{n}}{N} \mathrm{X} 100 \% \\
& \%=\text { Persentase } \\
& \mathrm{n}=\text { Nilai yang diperoleh } \\
& \mathrm{N}=\text { Jumlah seluruh nilai }
\end{aligned}
$$

Agar hasil penelitian berupa pernyataan kuantitatif, maka besarnya persentase rata-rata dijadikan dasar bagi penentuan predikat dalam bentuk kategorisasi efektif, cukup efektif, kurang efektif, dan tidak efektif.

\section{HASIL PENELITIAN PEMBAHASAN}

Efektivitas merupakan suatu keadaan di mana terjadi kesesuaian antara tujuan yang telah ditetapkan sebelumnya dengan hasil yang telah dicapai. Pengertian efektivitas secara umum menunjukkan sejauh mana rencana dapat tercapai sesuai dengan tujuan yang telah ditentukan. Kinerja pegawai merupakan suatu prestasi kerja atau hasil kerja baik secara kualitas maupun kuantitas yang dicapai oleh seorang pegawai dalam melaksanakan tugas sesuai tanggung jawab 
yang diberikan. Di dalam kinerja terdapat standar ukuran tertentu untuk mengetahui keberhasilan dan prestasi seseorang atau kelompok.

Penelitian ini berusaha menjawab satu permasalahan pokok, yaitu bagaimana efektivitas kinerja pegawai di Kantor Kelurahan Lanrisang Kecamatan Lanrisang Kabupaten Pinrang. Setelah data hasil penelitian disajikan, maka diketahui bahwa efektivitas kinerja pegawai di Kantor Kelurahan Lanrisang berada pada kategori efektif. Hal ini membuktikan PP 46 tahun 2011 tentang penilaian kinerja ASN bahwa umumnya efektivitas kinerja pegawai dapat diukur berdasarkan indikator SKP dan perilaku kerja.

\section{Sasaran Kerja Pegawai (SKP)}

Sasaran kerja pegawai adalah rencana kerja dan target yang akan dicapai oleh pegawai. Dalam sistem penilaian prestasi kerja, pegawai kantor Kelurahan Lanrisang wajib menyusun SKP sebagai rancangan pelaksanaan kegiatan tugas jabatan, sesuai dengan rincian tugas, tanggung jawab dan wewenangnya yang secara umum telah ditetapkan dalam struktur dan tata kerja. Hasil penelitian menunjukkan bahwa efektivitas kinerja pegawai ditinjau dari aspek sasaran kerja pegawai tergolong cukup efektif. Hal ini dapat dibuktikan dari segi kuantitas kerja dimana pegawai Kelurahan Lanrisang memiliki kemampuan dalam menghasilkan pekerjaan sesuai dengan target kerja yang telah ditetapkan. Hal tersebut terjadi dikarenakan pegawai cenderung menyelesaikan pekerjaan sebanyak-banyaknya daripada terjadi penumpukan kerja.

Kinerja pegawai Kelurahan Lanrisang telah mencapai standar kualitas kerja. Kualitas hasil kerja pegawai didukung oleh pengetahuan dan keterampilan yang dimiliki pegawai dalam menyelesaikan pekerjaan, meskipun masih ada sebagian kecil pegawai yang belum mampu menggunakan komputer dengan baik. Penggunaan waktu kerja pegwai Kelurahan Lanrisang telah mencapai standar, dimana pegawai mampu menyelesaikan pekerjaan dengan tepat waktu, namun belum semua pegawai mampu menyelesaikan pekerjaan lebih cepat pada saat dibutuhkan. Sedangkan penggunaan biaya secara efisien tergantung dari kemampuan kerja pegawai dan ide-ide yang digunakan untuk menyelesaikan pekerjaan serta kebijakan yang diambil.

\section{Perilaku Kerja}

Perilaku kerja merupakan tingkah laku atau sikap yang dilakukan atau tidak dilakukan oleh pegawai. Dari hasil penelitian diketahui bahwa perilaku kerja pegawai tergolong efektif, dalam hal ini dapat dilihat dari segi orientasi pelayanan di mana pegawai selalu memberikan pelayanan terbaik kepada kepada yang dilayani seperti melayani masyarakat dengan perlakuan yang sama, melayani atasan dengan baik dengan memahami keinginan atasan dan mengerjakan tugas dan tanggung jawab yang diberikan, serta merespon baik ketika rekan kerja minta bantuan. Selain itu, integritas pegawai di Kantor Kelurahan Lanrisang juga tergolong baik dengan kemampuan pegawai bertindak sesuai dengan nilai, norma dan etika, meskipun masih ada beberapa pegawai yang belum mampu bertindak sepenuhnya sesuai dengan nilai. Dari segi komitmen pegawai tergolong cukup baik, hal ini disebabkan oleh sebagian pegawai masih mengutamakan kepentingan diri sendiri daripada kepentingan dinas dengan datang terlambat 
dan pulang lebih cepat dari waktu yang telah ditentukan. Dalam hal ini, kedisiplinan pegawai Kantor Kelurahan Lanrisang masih perlu ditingkatkan dengan mengupayakan diri untuk datang dan pulang dengan tepat waktu.

Kerja sama dilakukan atas dasar tujuan yang dilakukan secara bersama-sama dalam suatu organisasi. Dari hasil penelitian menunjukkan bahwa kerja sama pegawai Kantor Kelurahan Lanrisang bersinergi, dikarenakan pegawai saling membantu dalam menyelesaikan pekerjaan, pegawai mengerjakan tugas dan tanggung jawab yang diberikan oleh atasan dengan baik, dan sebaliknya atasan selalu memberikan arahan kepada bawahannya serta menerima pendapat/saran dari para bawahannya. Pegawai Kelurahan Lanrisang memiliki jiwa kepemimpinan dikarenakan pegawai mampu memotivasi dan saling mengarahkan dalam menyelesaikan pekerjaan.

\section{SIMPULAN}

Berdasarkan hasil analisis data dan pembahasan yang diuraikan pada bab sebelumnya, maka hasil penelitian dapat disimpulkan bahwa tingkat efektivitas kinerja pegawai Kantor Kelurahan Lanrisang Kecamatan Lanrisang Kabupaten Pinrang berada pada kategori efektif, hal ini membuktikan bahwa pegawai Kelurahan Lanrisang telah mampu melaksanakan tanggungjawabnya, membina kerja sama yang baik dan dapat memberikan pelayanan administratif yang baik. Efektifnya standar kinerja pegawai pada Kantor Kelurahan Lanrisang Kecamatan Lanrisang Kabupaten Pinrang dilihat dari dua aspek yaitu; 1) Sasaran Kerja Pegawai (SKP) berada pada kategori cukup efektif dan 2) Perilaku Kerja berada pada kategori efektif.

\section{DAFTAR PUSTAKA}

Afrizal. (2009). Faktor-Faktor Pengambilan Keputusan Dan Efisiensi Serta Efektifitas Penempatan Pegawai Pada Sekretariat Daerah Provinsi Kepulauan Riau. Universitas Terbuka.

Ali, M. (2013). Penelitian Kependidikan Prosedur dan Strategi. Bandung: Angkasa.

Ambarwati, S. D. A. (2005). Managing productive performance appraisal: Sebuah upaya menjawab kebutuhan penilaian kinerja karyawan yang bebas KKN. Jurnal Siasat Bisnis.

Anas, S. (2014). Pengantar Statistik Pendidikan. Jakarta: Rajawali Press.

Brahmasari, I. A., \& Suprayetno, A. (2009). Pengaruh Motivasi Kerja, Kepemimpinan dan Budaya Organisasi Terhadap Kepuasan Kerja Karyawan serta Dampaknya pada Kinerja Perusahaan (Studi kasus pada PT. Pei Hai International Wiratama Indonesia). Jurnal Manajemen Dan Kewirausahaan, 10(2), pp-124.

Halim, A., \& Mas' ud, A. R. (2005). Manajemen pesantren. PT LKiS Pelangi Aksara.

Hariandja, M. T. E. (2002). Manajemen sumber daya manusia. Grasindo.

Haryadi, H. (2009). Administrasi Perkantoran untuk Manajer \& Staf. VisiMedia.

Nurillah, A. S., \& Muid, D. (2014). Pengaruh Kompetensi Sumber Daya Manusia, Penerapan Sistem Akuntansi Keuangan Daerah (Sakd), Pemanfaatan Teknologi Informasi, dan Sistem Pengendalian Intern Terhadap Kualitas Laporan Keuangan Pemerintah Daerah (Studi Empiris pada SKPD Kota Depok). Fakultas Ekonomika dan Bisnis. 
$6 \mid$ Jurnal Ad'ministrare: Jurnal Pemikiran Ilmiah dan Pendidikan Administrasi Perkantoran, Vol.4, No.1, 2017

Rahmanurrasjid, A. (2008). Akuntabilitas dan Transparansi Dalam Pertanggungjawaban Pemerintah Daerah untuk Mewujudkan Pemerintahan yang Baik di Daerah (Studi di Kabupaten Kebumen). Program Pascasarjana Universitas Diponegoro.

RE, S. C. (2003). Manajemen Sumber Daya Manusia.

Ruky, A. S. (2002). Sistem manajemen kinerja. Gramedia Pustaka Utama.

Siregar, A. N., \& Saridewi, T. R. (2016). Hubungan antara motivasi dan budaya kerja dengan kinerja penyuluh pertanian di Kabupaten Subang, Provinsi Jawa Barat. Jurnal Penyuluhan Pertanian, 5(1), 24-35.

Tadampali, A. C. T., Hadi, A., \& Salam, R. (2016). Pengaruh Iklim Organisasi terhadap Turnover Intention Melalui Kepuasan Kerja sebagai Variabel Intervening pada PT Bank SulSelBar. Jurnal Ilmiah Ilmu Administrasi Publik, 6(2), 35-46.

Wawointana, T., Akib, H., Tahmir, S., \& Kerebungu, F. (2016). Role of Local Institutions "Mapalus" as a Basis of Public Service in the Field of Security and Public Order in Minahasa, Indonesia. The Social Sciences, 11(13), 3370-3374.

Wenda, W. L., \& Akib, H. (2015). Pembangunan Ekonomi dalam Era Otonomi Daerah di Kabupaten Pegunungan Bintang, Indonesia. Jurnal Ilmiah Ilmu Administrasi Publik, 5(1), 43-51. 